\title{
REELABORAÇÃO DISCURSIVA DE UM TEXTO DE DIVULGAÇÃO CIENTÍFICA SOBRE CRISE HÍDRICA EM UM LIVRO DIDÁTICO DE CIÊNCIAS
}

\section{DISCURSIVE RE-ELABORATION OF A POPULAR SCIENCE TEXT ABOUT WATER CRISIS INTO A SCIENCE TEXTBOOK}

\author{
Mylena Guedes Passeri ${ }^{1}$, Rafaela Magalhães Aires ${ }^{2}$, Marcelo Borges Rocha ${ }^{3}$ \\ ${ }^{1}$ Centro Federal de Educação Tecnológica Celso Suckow da Fonseca, mylena.passeri@ gmail.com \\ ${ }^{2}$ Centro Federal de Educação Tecnológica Celso Suckow da Fonseca, rafaelaaires@ yahoo.com.br \\ ${ }^{3}$ Centro Federal de Educação Tecnológica Celso Suckow da Fonseca, rochamarcelo36@ yahoo.com.br
}

\section{RESUMO}

Neste trabalho investigamos as reelaborações discursivas de um texto de divulgação científica (TDC) sobre a crise hídrica inserido em um livro didático de ciências. A divulgação científica é um instrumento que busca a democratização do acesso a informação científica para o público em geral, apresentando-se com um discurso próprio. Sendo assim, caracteriza-se como um importante recurso para o ensino no que diz respeito a abordagem de assuntos sociocientíficos, dentre os quais merecem destaque, os problemas ambientais, pelos os riscos que inferem a sociedade. No entanto, considera-se necessárias as reelaborações discursivas para torná-lo mais didático ao entendimento dos estudantes. No presente estudo foi feita uma análise qualitativa do TDC e das reelaborações sofridas para o texto didático, apresentando-se inferências sobre os impactos do seu aproveitamento no ensino. Nossos resultados apontam para uma grande redução de conteúdo, o que pode implicar numa abordagem superficial sobre a problemática apresentada, não agregando informações reflexivas e atuais.

Palavras-chave: divulgação científica, ensino de ciências, livro didático, reelaboração discursiva.

\begin{abstract}
This paper investigates the operations of discursive reelaboration of a popular science text on the water crisis into a science textbook. Popular Science is an instrument that seeks a democratization of access to scientific information., for the general public, presenting itself with a discourse of its own. Therefore, the popular science text can be a potential tool for teaching about the approach of socio-scientific subjects, among them the environmental problems due to risks that infers the society. However, it is considered necessary to discursive re-elaborations to make it more didactic to students' understanding. In the present study, a qualitative analysis of the didactic text and reelaborations undergone for the didactic text was carried out, presenting inferences about the impacts of its use in teaching. Our results point to a great reduction of content, which may imply a superficial approach on the presented problem, not adding reflective and current information.
\end{abstract}

Key words: popular science, science teaching, science textbook, discursive reelaboration. 


\section{Ensino, Saúde e Ambiente - V10 (1), pp. 142-162, Abril. 2017}

\section{O PAPEL SOCIAL DA DIVULGAÇÃO CIENTÍFICA}

Questões pertinentes à Natureza da Ciência incluem seu entendimento como uma atividade humana, falível, não neutra e influenciada por aspectos históricos, culturais, ideológicos, econômicos, políticos e sociais. A partir desse viés, o entendimento adequado de como ocorre a produção do conhecimento científico e tecnológico e dos assuntos relacionados a essa área tão imersa no cotidiano da sociedade se mostra fundamental para a compreensão da realidade vivenciada e para uma participação bem informada e refletida na tomada de decisões (BRASIL, 1998; GIL PÉREZ et al., 2001; PRAIA et al., 2007).

Nesse contexto, a Divulgação Científica (DC) se caracteriza como um meio de acesso à informação científica para a população em geral (LOUREIRO, 2003; TARGINO, 2007; ZAMBONI, 1997). Silva (2006, p. 53) traz que "o termo divulgação científica, longe de designar um tipo específico de texto, está relacionado à forma como o conhecimento científico é produzido, como ele é formulado e como ele circula numa sociedade [...]". Bueno (1985, p. 1421) informa que a DC compreende "a utilização de recursos, técnicas e processos para a veiculação de informações científicas e tecnológicas ao público em geral".

Enfim, apesar das diferentes nuances entendidas por variados autores, como apontado por Grillo, Dobranszky e Laplane (2004), parece consensual a ideia de que a DC está relacionada a atividades que levem a democratização do acesso a informação científica através de processos que informem o público leigo sobre a ciência, incluindo a reformulação/transcrição de uma linguagem especializada para uma linguagem acessível e a utilização de um discurso próprio da DC para alcançar tal objetivo.

Nesse sentido, entende-se a relevância do papel social que a DC apresenta ao ser um meio através do qual a sociedade geral pode ter contato com as informações científicas e tecnológicas e estar mais preparada para a discussão e para a tomada de decisões em relação a esses assuntos (CALDAS, 2010; LOUREIRO, 2003; TARGINO, 2007).

Considerando que quase tudo que acontece na sociedade é influenciado pela C\&T, é preciso que o discurso científico seja amplamente compreendido pela população, para que possa tomar suas decisões a partir de múltiplas informações, considerando os aspectos positivos e negativos de cada situação. Não se trata, obviamente, de negar a especificidade dos saberes, nem de abrir mão deles, mas, sim, de possibilitar a participação efetiva da sociedade em debates públicos sobre temas polêmicos, como transgênicos, biotecnologia, energia nuclear, entre tantos outros, cujos impactos sociais são inegáveis (CALDAS, 2010, p. 33).

Em entrevista à revista Ciência e Cultura, Barata (2008) fala sobre algumas 
dificuldades encontradas na atividade de DC:

Um dos maiores desafios da divulgação científica é escolher corretamente a linguagem com que você vai se dirigir à sua audiência. [...]. Outra coisa essencial é relacionar ciência à vida das pessoas. Mostrar como o cotidiano depende das descobertas científicas, como o futuro será forjado por elas, desde aplicações tecnológicas até questões mais fundamentais, como a origem do universo e da vida ou o de como o cérebro cria a consciência (BARATA, 2008, não paginado).

\section{A DIVUlgaÇão CIENTÍFICA NO ENSINO DE CIÊNCIAS: ABRINDO O LIVRO DIDÁTICO.}

A articulação entre as diversas fontes de informações e o ensino é recomendada nos Parâmetros Curriculares Nacionais (BRASIL, 1998) como forma de superar e complementar o uso do livro didático (LD), ferramenta educacional amplamente utilizada no ensino escolar. Assim, a DC, em especial através dos textos e/ou folhetos de jornais, revistas e mídias digitais, se apresenta como uma potencial ferramenta para abordar assuntos sociocientíficos no ensino, contextualizando o aprendizado de conteúdos escolares e tornando-o mais atrativo.

As possibilidades de utilização das matérias de jornal e revistas são muitas: podem ser fontes de informação, de problematização, de ilustração ou ampliação para um tema tratado em sala de aula. Os próprios estudantes podem cooperar na reunião e classificação de artigos, organizar painéis temáticos, por exemplo, para temas transversais que estão sendo alvo de trabalho em um dado período letivo (BRASIL, 1998, p. 128).

Dentre os assuntos sociocientíficos abordados, os problemas ambientais merecem destaque pelos riscos que apresentam ao equilíbrio ecológico e a qualidade de vida da população, construindo-se como foco de um dos eixos educacionais: o de Meio Ambiente. Além disso, a constante aparição desses assuntos nos meios de comunicação tem capacidade de influenciar na formação de opiniões dos estudantes e, portanto, requer uma abordagem problematizadora no ensino, em especial, no Ensino de Ciências, por suas aproximações curriculares. Os Parâmetros Curriculares Nacionais apontam que "a Ciência deve ser apreendida em suas relações com a Tecnologia e com as demais questões sociais e ambientais" (BRASIL, 1998, p. 21).

A partir do exposto, cabe alguns questionamentos interessantes sobre o processo de inserção de texto de Divulgação Científica nos livros didáticos. Em que espaços os textos de Divulgação Científica são abordados nos livros didáticos? Quais informações são privilegiadas, substituídas ou omitidas ao utilizar um texto de Divulgação Científica nos livros didáticos? Qual(is) o(s) atore(s) envolvido(s) nesse processo de reelaboração discursiva? Como os aspectos da Natureza da Ciência são 
tratados no texto de Divulgação Científica e como são aproveitados no texto didático? Para tal propósito, torna-se importante o entendimento de alguns aspectos relacionados ao discurso da DC e ao processo de reelaboração discursiva.

\section{O DISCURSO DA DIVULGAÇÃO CIENTÍFICA}

Grigolleto (2005) assume o discurso da DC sendo gerado a partir da ciência e com aval e definição do jornalista, que assume um papel de jornalista científico. Para a autora, o discurso da DC é próprio do campo, incluindo saberes e linguagens dos meios jornalístico, científico e do senso comum, representando um deslocamento a partir do discurso científico. Aponta-se ainda que há o discurso gerado a partir de um cientista divulgador, no qual parece haver uma tentativa maior de homogeneidade ao discurso, favorecendo ainda mais a ideia de neutralidade e verdade da ciência.

De qualquer forma, o discurso da DC é considerado "constitutivamente heterogêneo e atravessado pelo ideológico" (GRIGOLLETO, 2005, p. 258), sendo afetado pelos conhecimentos científicos, pelo meio social e pelos aspectos históricos. Assume-se, assim, uma rede complexa de discursos que varia de acordo com quem escreve, o meio no qual está inserido e o receptor (leitor) do texto.

De maneira aproximada a esta visão, Targino (2007, p. 22) infere que o discurso da DC representa uma interseção entre o discurso jornalístico e o científico, mas que apresenta variações de acordo com o contexto no qual está sendo produzido. A autora enfatiza ainda que "Cientistas e jornalistas, como qualquer indivíduo, não se despem das próprias escalas de valores ao exercer o seu ofício”.

Cabe destacar que a autora distingue jornalismo científico como uma modalidade da DC e não como um sinônimo de tal atividade. Para a autora, o jornalismo científico é voltado ao grande público, enquanto que a DC pode ser percebida voltada para um público específico em determinadas situações. Entretanto, algumas outras colocações vão ao encontro do que é assumido neste trabalho e são relatadas a seguir.

Sobre o discurso científico, Targino (2007, p. 21) aponta que:

(...) prima por um padrão léxico, em que as nominalizações e os termos ou jargões técnicos, acessíveis só aos especialistas, prevalecem. Apresenta, ainda, estas características: (1) emprego usual da 3a pessoa do singular (que, acrescida da partícula se, evidencia indeterminação do sujeito) ou da 1a pessoa do plural (sujeito universal); (2) concisão ou economia linguística [sic]; (3) precisão ou cuidado máximo com ambiguidades [sic]; (4) objetividade ou rejeição a traços inerentes à linguagem afetiva, pautada pela expressão de sentimentos, que o autor vivencia ou que deseja provocar no 
ânimo do interlocutor; (5) formalismo ou exclusão de termos do dia-a-dia ou de uso vulgar.

Essas características elencadas por Targino (2007) promovem e enfatizam a visão deformada da ciência, assumindo caráter neutro e pretensioso de verdade absoluta, como já apontado por Grigolleto (2005), outros estudiosos sobre a Natureza da Ciência, como Gil Pérez et al. (2001) e Praia et al. (2007), além de documentos da área educacional como os Parâmetros Curriculares Nacionais (BRASIL, 1998).

Já em relação ao discurso jornalístico, Targino (2007, p. 23) informa que se baseia em seis questões: “o que aconteceu, quando, quem está envolvido no fato, onde ocorreu, como e o porquê", assumindo o caráter informativo e priorizando a apresentação de notícias com linguagem acessível, de forma clara, objetiva e concisa.

Por fim, sobre o discurso da DC, a autora coloca que há uma fusão de elementos dos dois discursos anteriores. Chama atenção, ainda para o fato de que:

(...) o discurso de DC não se limita à "tradução" ou à reformulação do discurso científico para amenizar ou diluir a sua eventual obscuridade. Tratase da formulação de novo discurso, com traços próprios e marcantes, cujo processo, a bem da verdade, está sujeito a riscos de distorção, no sentido de simplificar em demasia, mistificar, deturpar ou usurpar (TARGINO, 2007, p. 25)

Aproximando-se do posicionamento de Grigolleto (2005), Targino (2007, p.25) ressalta que "o direcionamento da DC também depende das intenções dos seus idealizadores, das informações priorizadas e dos métodos empregados", indicando que:

(...) compete ao divulgador de ciência, sem desvirtuar a essência do conhecimento científico, seguir parâmetros mínimos, quais sejam: clareza, concisão, proximidade e atualidade, simplicidade e brevidade na exposição dos fatos do presente, que mantêm algum tipo de relação com o público. Também menciona-se como característica do discurso de DC a correção gramatical, qualidade indispensável a qualquer discurso, seja literário, científico e jornalístico.

Zamboni (1997), por outro lado, não entende o discurso da DC como uma reformulação ou um mero deslocamento do discurso científico. A autora traz a ideia de um discurso de DC diferente do discurso científico, se constituindo em um novo discurso, produzido em condições e com finalidades específicas, longe do campo científico. Assim, resulta na instituição de um gênero de discurso com características específicas, apresentando certo padrão. Para a autora, os discursos jornalístico e didático estão vinculados ao da DC, estando inseridos no campo de transmissão de informações e tornando a linguagem dos textos acessíveis a um determinado público.

Três aspectos são ressaltados por Zamboni (1997) a partir dos estudos de Bakthin para caracterizar o discurso da DC: conteúdo temático (tratam sobre assuntos da ciência), estilo verbal (utilizam de analogias, generalizações, aproximações, 


\section{Ensino, Saúde e Ambiente - V10 (1), pp. 142-162, Abril. 2017}

comparações e simplificações, o que facilita o processo de vulgarização da ciência) e construção composicional (realizam a retomada de saberes científicos tácitos e o uso de estratégias para aproximação com o leitor como apelo inicial do texto e uso de suspense).

Orlandi (2001) defende que o discurso é relativo ao contexto em que está inserido e é variável dependendo do emissor, do receptor e do contexto social no qual está sendo desenvolvido. Assim, acrescenta a variante do discurso usado no dia a dia ao caracterizar o discurso da DC sendo formado pela relação entre dos discursos científico, jornalístico e cotidiano.

Gomes (1995) assume o papel de divulgador científico como um jornalista especializado em "traduzir" os textos científicos para a linguagem do público geral e estuda os fenômenos linguísticos ocorridos num processo de reelaboração de matérias jornalísticas a partir de entrevistas realizadas com cientistas. Para realizar sua análise, a autora assume operações realizadas durante o processo de reelaboração: acréscimo de informações, eliminação, substituições e reordenações.

Como pode ser percebido, não há consenso quanto a uma definição para o discurso da DC e esta não é a função deste estudo. Assume-se, aqui, que a DC possui um discurso próprio e diferente do discurso científico, com características e finalidades específicas, aproximando-se da visão de Zamboni (1997).

Dado o exposto, entende-se as possibilidades de variantes que podem ser observadas e interpretadas em um discurso de DC. Pensando na possibilidade de uso destes textos de Divulgação Científica (TDC) no ensino, em especial através do LD, considera-se ainda a ocorrência de reelaborações discursivas, principalmente, no sentido de torná-lo didático para o entendimento dos estudantes. Trabalhos que permeiam a investigação nesse contexto e inspiram o presente trabalho são encontrados em Gomes (1995), Nascimento (2005) e Souza e Rocha (2014).

Assim, percebendo o quão complexas podem ser as mudanças sofridas em relação a forma como o conhecimento dos aspectos sociocientíficos chegam aos alunos, destaca-se a importância de estudos sobre o discurso da DC, em especial, quando reelaborado para o uso no LD pela sua relevância como instrumento educacional escolar. No presente trabalho buscamos explorar as operações de reelaboração discursiva determinadas em um TDC sobre a crise hídrica para um LD de ciências. Pretende-se ainda reconhecer uma caracterização básica do discurso de DC no TDC e refletir sobre as funções das reelaborações realizadas para o LD. 
Ensino, Saúde e Ambiente - V10 (1), pp. 142-162, Abril. 2017

\section{METODOLOGIA}

No presente estudo foi feita uma análise qualitativa (GIL, 2010) a partir de um texto didático (TD) presente em um livro de ciências destinado ao sexto ano do ensino fundamental e recomendado pelo Programa Nacional do Livro Didático. Para o estudo fez-se necessário que o TD apresentasse a fonte, o que em muitos casos impossibilitou a análise, pois a mesma não foi mencionada. Ainda para cumprir a proposta deste trabalho era necessário que a fonte do TD fosse um TDC. Atendendo a estes critérios, o texto selecionado e utilizado para este estudo foi encontrado no livro Ciências $6^{\circ}$ ano Planeta Terra (GEWANDSZNAJDER, 2012). O texto contempla questões ambientais acerca do risco de escassez da água e seus usos.

O TDC, fonte para o TD analisado, foi encontrado no endereço eletrônico da revista Superinteressante1, na edição de maio de 2003 e atualizado pela última vez em outubro de 2016, intitulado "Vai faltar água?", e de autoria dos jornalistas Adriano Quadrado e Rodrigo Vergara.

Inicialmente, apresenta-se uma análise interpretativa do TDC no intuito de informar sobre seu conteúdo e características relevantes para o estudo. Para a realização da análise do TD foram considerados alguns parâmetros de operações estabelecidos por Gomes (1995) a partir da comparação com o TDC, tais como: eliminação, substituição e/ou reordenação e acréscimo.

\section{RESULTADOS E DISCUSSÃO}

\section{O TEXTO DE DIVULGAÇÃO CIENTÍFICA}

O TDC analisado neste estudo conta com cerca de 2500 palavras distribuídas em 23 parágrafos, não apresentando imagens ou elementos gráficos. Ao final do texto são informadas outras fontes de consulta: três livros e cinco endereços eletrônicos. Seu tema é a grande problemática atual envolvendo a escassez dos recursos hídricos disponíveis para consumo humano. A seguir, o texto é apresentado e caracterizado.

Inicialmente, são apresentadas as proporções dos tipos de água encontrados no planeta e o quanto dessa água é própria para uso. A primeira problemática abordada no texto é o aumento do consumo de água devido ao aumento da população, indicando ainda a distribuição desigual dos recursos hídricos no planeta.

O Brasil é apontado como a maior reserva de água mundial, sendo considerado

\footnotetext{
${ }^{1}$ Disponível em: http://super.abril.com.br/saude/vai-faltar-agua/. Acessado em dezembro de 2016.
} 


\section{Ensino, Saúde e Ambiente - V10 (1), pp. 142-162, Abril. 2017}

um dos líderes estratégicos nas discussões internacionais sobre o assunto. O país é considerado detentor de instrumentos legais e tecnológicos valiosos para a preservação da água. Apesar disso, menciona-se que a existência de leis por si só não traz benefícios reais para a preservação da água e qualidade de vida da população, sendo esta afetada pela falta de saneamento básico, poluição e distribuição desigual desse recurso. O texto aponta também que uma das consequências da grande capacidade hídrica no território brasileiro propicia uma forte cultura de desperdício.

Os autores comparam diferentes olhares de ambientalistas e outros atores sociais envolvidos, apresentando expectativas mais catastróficas e outras mais otimistas. Ambientalistas defendem que a água pertence a todos. De maneira oposta a essa convicção, o mundo empresarial a vê como fonte de grandes lucros, principalmente no que diz respeito a saneamento e distribuição.

Algumas estratégias, como a drenagem de águas subterrâneas, o transporte de água e os bloqueios e desvios do curso de rios, utilizadas para lidar com a problemática em questão, e alguns de seus impactos para o ambiente e para a população são também comentados. Os conflitos relacionados as disputas por este recurso em diversas regiões do mundo, como Israel, África e Ásia, são ainda explorados do TDC. Assim, o texto apresenta questões complexas de geopolítica relacionadas a exploração da água, além de apresentar termos léxicos relacionados ao assunto, como ilustrado em: “A drenagem de aqüíferos [sic] subterrâneos pode baixar o nível de rios e lagos e causar ou agravar a desertificação".

Sobre as taxas de consumo, o texto informa como os setores de agricultura e indústria consomem e desperdiçam mais água do que o setor de uso humano (entendido como para uso doméstico). Em relação ao desperdício na agricultura são apontadas soluções vindas das novas tecnologias a fim de amenizar tal situação. Indica, ainda, a educação ambiental como um grande aliado na preservação deste recurso.

Os autores deixam para o final a grande questão que permeia e inicia uma abordagem quanto a valorização da água comparada a do petróleo. Traz ainda algumas questões para reflexão, como: Quem deve gerenciar as reservas de água e como deve ser feito? Como se dá a interferência das transnacionais na mercantilização da água e o que isso implica no acesso a esse recurso pela população em geral?

Em relação a linguagem, o TDC apresenta características próprias do gênero, seguindo o padrão de um discurso específico, marcado com estruturas linguísticas, gramaticais e lexicais que favorecem a construção do conhecimento científico 


\section{Ensino, Saúde e Ambiente - V10 (1), pp. 142-162, Abril. 2017}

(ZAMBONI, 1997). Algumas características identificadas por Zamboni (1997) como presentes no discurso da DC, são observadas no texto em questão e comentadas a seguir. O apelo inicial à leitura foi identificado no título a partir de seu destaque em relação ao restante do texto, já que está em tamanho maior e em negrito, assim como pelo formato de pergunta em que se apresenta: "Vai faltar água? ". Recursos à atratividade, como uso de box ou de imagens no TDC, são indicados pela autora, mas não foram encontrados no texto analisado no presente estudo.

A atitude de cautela e prudência diante dos resultados da pesquisa pode ser percebida, por exemplo, a partir da apresentação de diferentes visões sobre a crise hídrica e ações antrópicas relacionadas a esta situação, mostrando que não há um consenso absoluto nas perspectivas sobre este tema e que as soluções tecnológicas apresentadas também apresentam várias consequências negativas, precisando ser ponderadas. Além disso, o texto possui as falas de diversos especialistas e representantes de instituições, o que pode passar uma sensação de confiabilidade ao texto, como expõem Cunha e Giordan (2009, não paginado): "nos textos de divulgação científica, o cientista aparece como um personagem para dar credibilidade ao texto".

Outra característica que Zamboni (1997) indica em um TDC é a presença de procedimentos explicativos, que lhes conferem um traço de didaticidade. No texto "Vai faltar água?" percebe-se o uso deste recurso ao final de alguns parágrafos, nos quais os autores usam o termo "Resumindo: (...)" no início da frase para sintetizar e/ou simplificar alguma informação anteriormente tratada no parágrafo. Em outros trechos é observada a presença de explicações no meio das frases para definir ou apresentar um termo mais técnico, como destacado em: "Mas essa estratégia é perigosa, sobretudo porque esses reservatórios subterrâneos, chamados de aquíferos [sic], se renovam muito mais vagarosamente do que rios e lagos".

Em vários momentos o texto apresenta um caráter de interlocução direta com o leitor, mais uma característica informada por Zamboni (1997), por exemplo, pelo uso da terceira pessoa do singular (explícita e implicitamente), como nos trechos: "Tudo bem, você pode pensar. Usa-se a água enquanto ela existe. Mas os efeitos dessa retirada vão mais além", "Veja o caso da drenagem, por exemplo" e "Portanto, ao ler essa reportagem, você está fazendo a sua parte". Tal característica pode ser atribuída a intenção de aproximação entre o leitor e o texto.

Por fim, em relação a tessitura lexical, encontra-se a presença de muitos termos técnicos, nem todos com explicações, como "bacia transnacional", "saneamento básico" 
e "mananciais". O texto aborda, ainda, vários números e estatísticas, além de questões históricas, políticas e geográficas, que exigem conhecimentos específicos sobre essas áreas para um completo entendimento da mensagem. Apesar disso, a linguagem usada é coloquial, o que pode favorecer o entendimento e a atratividade do texto.

Assim, o texto "Vai faltar água?", apresenta diversos elementos característicos do gênero de discurso da DC. Apesar de algumas exceções, como a tessitura lexical densa que o texto apresenta, muitas das suas características estão relacionadas ao objetivo final de TDC: a informação sobre questões científicas para um público não especializado, utilizando de explicações e linguagem coloquial.

Ressalta-se que a abordagem de aspectos sociais, políticos, econômicos e ambientais relacionados à crise hídrica pode favorecer a reflexão crítica dos indivíduos sobre os assuntos. Acredita-se que, desta forma, os leitores são mais bem informados e preparados para a tomada de decisão.

\section{ANÁLISE DO TEXTO DIDÁTICO}

A evolução das tecnologias permite aos estudantes o acesso a uma grande gama de conhecimento. No entanto, é necessário formar um estudante com leitura crítica e consciente capaz de compreender e difundir as informações de forma atualizada e contextualizada (BRASIL, 1998). Neste sentido, acredita-se a inserção de TDC nos LD favoreça o processo de aprendizagem, de maneira que possibilite uma estratégia didática, onde o professor possa utilizar tais texto para aprimorar a leitura crítica e, concomitantemente, contextualizar e complementar o conteúdo abordado nos capítulos. É necessária a compreensão de como estes textos foram adaptados e selecionados para serem incluídos nos LD.

O TDC sofreu diversas adaptações para ser inserido no LD. O TD, conta com cerca de 500 palavras distribuídas em 6 parágrafos, apresentando o mesmo título do texto original. Sua inserção foi feita na unidade 3 do livro (tema: “A água”), no final do capítulo 9 (sobre "Os estados físicos da água"), na parte de exercícios, na seção "De olho no texto". Acrescenta, ainda, uma imagem que ilustra o desperdício de água, com a legenda "Lançamento de água no eixo Itaqui-Bacanga (MA), jan. 2012", ao final do grupo de cinco exercícios que seguem o texto.

Figura 1: Imagem inserida no TD ao final dos exercícios que seguem o texto representando um vazamento de água no Maranhão (MA). 


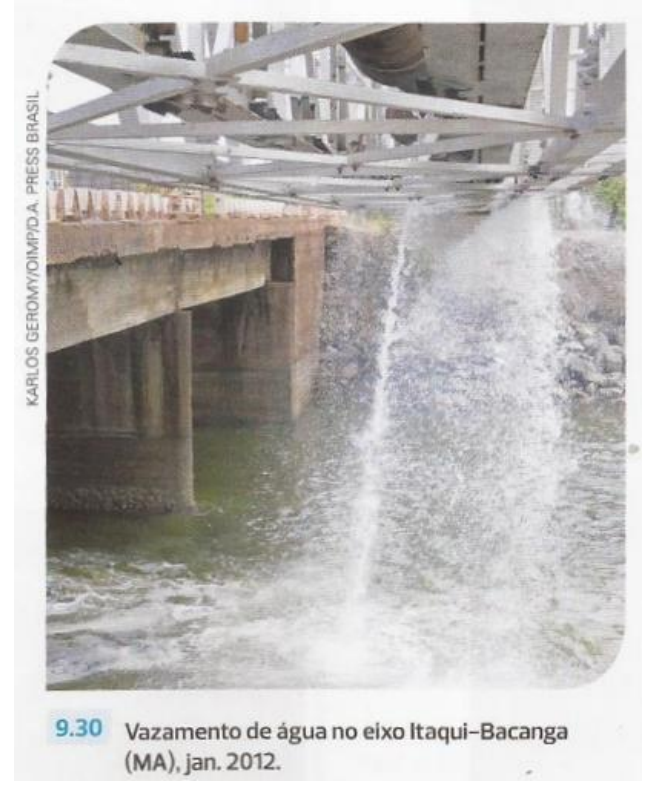

Fonte: Gewandsznajder, F. Ciências $6^{\circ}$ ano - Planeta Terra. Projeto Teláris, $1^{\text {a }}$ edição, Editora Ática, 2012, p. 135.

Embora não tenha sido foco deste estudo, informa-se que as perguntas seguintes ao texto abordam: a) aparência do planeta Terra e sua ilusão quanto a quantidade de água disponível para consumo; b) significado das palavras incolor, insípido e inodoro; c) ciclo da água como justificativa para a quantidade da água não ser alterada no planeta; d) distribuição de água relacionada a densidade populacional; e, por fim, e) gráfico com a proporção de uso da água pelos setores industrial, agrícola e doméstico.

Sobre a reelaboração sofrida no texto, inicialmente, fica claro pela extensão do TD que muitas partes foram suprimidas em relação ao TDC. O texto adaptado para o LD se apresenta simplista em relação as possibilidades de abordagens oferecidas pelo texto original. Diversas questões que permeiam o uso e o consumo desse recurso, por exemplo os conflitos geopolíticos, não são mencionados. Assim, percebe-se um baixo aproveitamento das situações apresentadas no TDC. Talvez essa opção tenha sido feita pensando no público alvo do LD (alunos do sexto ano do ensino fundamental), no tema (estados físicos da água) em que o texto está sendo aproveitado e/ou no espaço disponível neste instrumento para inserir o texto.

A seguir, apresentam-se quadros comparativos entre o TDC e sua versão adaptada para o LD. Os trechos que sofreram reelaboração são destacados conforme as operações realizadas: eliminação (negrito), substituição (sublinhado), reordenação (sublinhados e em negrito) e acréscimo (itálico).

O quadro 1 apresenta um comparativo do $1^{\circ}$ parágrafo de ambos os textos. 
Quadro 1: Comparação entre TDC ( $1^{\circ}$ e $2^{\circ}$ parágrafos) e TD ( $1^{\circ}$ parágrafo), apresentando substituição e eliminação.

\begin{tabular}{|c|c|}
\hline Texto de divulgação científica & Texto didático \\
\hline $\begin{array}{l}\text { Quem vê uma foto do planeta feita do espaço } \\
\text { pode pensar que água é algo que nunca vai faltar. } \\
\text { Afinal, esse líquido incolor, insípido e inodoro, } \\
\text { vital para a vida, ocupa mais de dois terços da } \\
\text { superfície da Terra. Nada mais enganoso. A } \\
\text { quantidade de água no planeta, de fato, não se } \\
\text { altera. Desde que o globo se esfriou, há muitos } \\
\text { milênios, são os mesmos } 1,4 \text { bilhão de } \\
\text { quilômetros cúbicos. Mas só podemos usar uma } \\
\text { gota desse manancial. Primeiro porque } \\
\text { precisamos de água doce. E só } 2,5 \% \text { da água do } \\
\text { mundo é doce. Dessa pequena parte, tire dois } \\
\text { terços, confinados nas calotas polares e no gelo } \\
\text { eterno das montanhas. Do que sobrou, } \\
\text { desconsidere a maior parte, escondida no subsolo. } \\
\text { Resultado: a água pronta para beber e fácil de } \\
\text { captar está nos rios e lagos, num total de } 90 \text { mil } \\
\text { quilômetros cúbicos, ou } 0,26 \% \text { do estoque } \\
\text { mundial. Mas nem essa porção está } \\
\text { inteiramente disponível. Para não esgotar o } \\
\text { precioso líquido, só podemos utilizar a água } \\
\text { renovável pelas chuvas. } \\
\text { E aí chegamos a um limite de consumo de } 34 \\
\text { mil quilômetros cúbicos anuais, ou } 0,002 \% \text { das } \\
\text { águas do planeta. Nem uma gota a mais. Como } \\
\text { diz em seu livro Água o jornalista canadense } \\
\text { Marq de Villiers: “A água pode ser poluída, } \\
\text { maltratada e mal utilizada, mas não é criada } \\
\text { nem destruída”. }\end{array}$ & $\begin{array}{l}\text { Quem vê uma foto do planeta feita do espaço } \\
\text { pode pensar que água é algo que nunca vai faltar. } \\
\text { Afinal, esse líquido incolor, insípido e inodoro, } \\
\text { vital para a vida, ocupa mais de dois terços da } \\
\text { superfície da Terra. Essa ideia, no entanto, é } \\
\text { bastante enganosa. A quantidade de água no } \\
\text { planeta, de fato, não se altera. Desde que o globo } \\
\text { se esfriou, há muitos milênios, são os mesmos } 1,4 \\
\text { bilhão de quilômetros cúbicos. Mas só podemos } \\
\text { usar uma gota desse manancial. Primeiro porque } \\
\text { precisamos de água doce. E só } 2,5 \% \text { da água do } \\
\text { mundo é doce. Dessa pequena parte, tire dois } \\
\text { terços, confinados nas calotas polares e no gelo } \\
\text { eterno das montanhas. Do que sobrou, } \\
\text { desconsidere a maior parte, escondida no subsolo. } \\
\text { Resultado: a água pronta para beber e fácil de } \\
\text { captar está nos rios e lagos, num total de } 90 \text { mil } \\
\text { quilômetros cúbicos, ou } 0,26 \% \text { do estoque } \\
\text { mundial. }\end{array}$ \\
\hline
\end{tabular}

Fonte: Autoria própria.

A substituição observada no TD no quadro 1 pode ter sido realizado com o intuito de tornar o texto mais explicativo ou suavizar o uso da expressão "Nada". Na sentença destacada no TDC está implícito que o "engano" se refere as ideias apresentadas na frase anterior. Na reelaboração, a substituição para a sentença "Essa ideia, no entanto, é bastante enganosa", deixa explicito a que o "engano" se refere. As últimas frases do TDC foram eliminadas, provavelmente, por abordar questões que são debatidas em outros trechos do texto que não foram utilizados no TD. Um parágrafo inteiro abordando a quantidade limite de consumo de água do planeta e a fala de um jornalista sobre o assunto também foi eliminado do TDC.

No quadro 2 são apresentados o $3^{\circ}$ e $4^{\circ}$ parágrafos do TDC e o $2^{\circ}$ ao parágrafo do TD, onde é possível visualizar intensa supressão de informações. 
Quadro 2: Comparação entre TDC ( $3^{\circ}$ e $4^{\circ}$ parágrafos) e TD ( $2^{\circ}$ parágrafo), apresentando substituição e grandes eliminações.

\begin{tabular}{|c|c|}
\hline Texto de divulgação científica & Texto didático \\
\hline $\begin{array}{l}\text { Mas o ser humano se multiplica, e muito. A } \\
\text { população já soma } 6 \text { bilhões, e segue aumentando. } \\
\text { O consumo de água também cresce, mas com } \\
\text { um detalhe: em ritmo mais acelerado. Segundo } \\
\text { a Organização das Nações Unidas (ONU), o } \\
\text { crescimento do uso da água foi mais do que o } \\
\text { dobro do aumento populacional no século } \\
\text { passado, de maneira que, hoje, consumimos } \\
\text { metade do estoque disponível. Em 35 anos, } \\
\text { estima-se que o consumo terá dobrado, ou seja, } \\
\text { estaremos utilizando toda a água que o planeta } \\
\text { produz. Resumindo: não é apenas o aumento } \\
\text { populacional que preocupa, mas também o } \\
\text { consumo desenfreado. } \\
\text { Os problemas desse uso indiscriminado já } \\
\text { começaram, por um problema simples: } \\
\text { distribuição. Há muita água boa onde não } \\
\text { mora ninguém, e pouca água saudável em } \\
\text { áreas povoadas. Resultado: escassez. Segundo a } \\
\text { ONU, } 1,1 \text { bilhão de pessoas, um sexto da } \\
\text { população mundial, vivem sem água de boa } \\
\text { qualidade. O Brasil é um exemplo de que ter } \\
\text { água não basta. Apesar de sermos a maior } \\
\text { potência hídrica do planeta, há muita gente } \\
\text { vivendo situação de seca. Atualmente } 31 \text { países } \\
\text { sofrem com sérios problemas de escassez, } \\
\text { especialmente no Oriente Médio, no norte da } \\
\text { África e no sul da Ásia (leia quadro na pág. } \\
\text { 45). As projeções são ainda mais catastróficas: } \\
\text { se o consumo não se alterar, duas em cada três } \\
\text { pessoas estarão vivendo condições de escassez } \\
\text { em } 2025 .\end{array}$ & $\begin{array}{l}\text { A população já soma } 6 \text { bilhões, e segue } \\
\text { aumentando. Segundo a Organização das Nações } \\
\text { Unidas (ONU), o crescimento do uso da água foi } \\
\text { mais do que o dobro do aumento populacional no } \\
\text { século passado. Além disso, existe o problema da } \\
\text { distribuição: há muita água boa onde não mora } \\
\text { ninguém, e pouca água saudável em áreas } \\
\text { povoadas. O resultado é a escassez. Segundo a } \\
\text { ONU, } 1,1 \text { bilhão de pessoas, um sexto da } \\
\text { população mundial, vivem sem água de boa } \\
\text { qualidade. }\end{array}$ \\
\hline
\end{tabular}

Fonte: Autoria própria.

Todo o conteúdo do $5^{\circ}$ ao $12^{\circ}$ parágrafo do TDC foi eliminado na adaptação para o TD. Nesses trechos suprimidos, eram tratadas questões de saneamento básico, perspectivas sobre a sobrevivência em caso de escassez da água, conflitos entre países, o desperdício deste recurso finito e os efeitos das soluções tecnológicas utilizadas por populações antigas e atuais.

No TDC são apresentadas ainda diferentes percepções sobre o futuro da água: visões pessimistas catastróficas que preveem falta de água iminente, e outras otimistas, que depositam suas esperanças na educação ambiental, em leis que protegem esse recurso (principalmente no que se refere a indústria e agricultura) e no uso da tecnologia para enfrentar a crise. Já o TD não apresenta esta dualidade de visões. Tais assuntos são importantes para apresentar pontos de vista diferentes aos estudantes, que poderiam 
refletir sob variados aspectos a partir da leitura do texto.

A contaminação é outra problemática abordada no TDC como um fator que diminui ainda mais a porcentagem de água consumível. No TD essa questão é explanada, no entanto, as consequências deste fato para a sociedade apontadas no texto original foram suprimidas. A falta de aprofundamento na discussão pode ser visualizada no quadro 3 , onde parte do $13^{\circ}$ parágrafo do TDC é eliminado na reelaboração do TD no $3^{\circ}$ parágrafo.

\section{Quadro 3: Comparação entre TDC $\left(13^{\circ}\right.$ parágrafo $)$ e TD ( $3^{\circ}$ parágrafo $)$ apresentando eliminação.}

\begin{tabular}{|c|c|}
\hline Texto de divulgação científica & Texto didático \\
\hline $\begin{array}{l}\text { A qualidade da água é outro fator crucial. Nesse } \\
\text { caso, o alarme vem soando faz tempo. Nos países } \\
\text { em desenvolvimento, diz a ONU, até } 90 \% \text { do } \\
\text { esgoto é lançado nas águas sem tratamento. Todos } \\
\text { os anos, de } 300 \text { a } 500 \text { milhões de toneladas de } \\
\text { metais pesados, solventes, produtos tóxicos e } \\
\text { outros tipos de dejeto são jogados na água pelas } \\
\text { indústrias. Cerca de } 2 \text { bilhões de toneladas de } \\
\text { lixo são despejados em rios, lagos e riachos } \\
\text { todos os dias. A verdade é que a maioria dos } \\
\text { produtos químicos produzidos pelo homem } \\
\text { mais cedo ou mais tarde acaba em um curso ou } \\
\text { depósito de água. Uma das conseqüências disso } \\
\text { é que 80\% das doenças nos países pobres do } \\
\text { hemisfério sul estão relacionadas com a água } \\
\text { de baixa qualidade. }\end{array}$ & $\begin{array}{l}\text { A qualidade da água é outro fator crucial. Nesse } \\
\text { caso, o alarme vem soando faz tempo. Nos países } \\
\text { em desenvolvimento, diz a ONU, até } 90 \% \text { do } \\
\text { esgoto é lançado nas águas sem tratamento. Todos } \\
\text { os anos, de } 300 \text { a } 500 \text { milhões de toneladas de } \\
\text { metais pesados, solventes, produtos tóxicos e } \\
\text { outros tipos de dejeto são jogados na água pelas } \\
\text { indústrias. }\end{array}$ \\
\hline
\end{tabular}

Fonte: Autoria própria.

O quadro 4 apresenta o $14^{\circ}$ parágrafo do TDC e os $4^{\circ}$ e $5^{\circ}$ do TD, nos quais observa-se eliminações de trechos, o acréscimo de uma frase indicando a presença de uma imagem incluída no LD e reordenação de parágrafos.

\section{Quadro 4: Comparação entre TDC ( $\left(14^{\circ}\right.$ parágrafo) e TD $\left(4^{\circ}\right.$ e $5^{\circ}$ parágrafos $)$ apresentando eliminação, acréscimo e reordenação.}

\begin{tabular}{|c|c|}
\hline Texto de divulgação científica & Texto didático \\
\hline $\begin{array}{l}\text { Mas, apesar de ser um recurso tão frágil e } \\
\text { escasso, a água ainda é muito desperdiçada. De } \\
\text { toda a água utilizada, } 10 \% \text { vai para o consumo } \\
\text { humano, } 20 \% \text { fica com a indústria e o restante, } \\
70 \% \text {, é utilizado na agricultura. Porém o } \\
\text { desperdício e o uso irracional são uma } \\
\text { constante em todos esses setores. Vazamentos, } \\
\text { métodos obsoletos e desperdício drenam cerca de } \\
50 \% \text { da água usada para beber e } 60 \% \text { da água de } \\
\text { irrigação. Com a tecnologia disponível } \\
\text { atualmente, a agricultura poderia reduzir sua taxa }\end{array}$ & $\begin{array}{l}\text { Mas, apesar de ser um recurso tão frágil e } \\
\text { escasso, a água ainda é muito desperdiçada. De } \\
\text { toda a água utilizada, } 10 \% \text { vai para o consumo } \\
\text { humano, } 20 \% \text { fica com a indústria e o restante, } \\
70 \% \text {, é utilizado na agricultura. No entanto, } \\
\text { vazamentos e desperdícios drenam cerca de } 50 \% \\
\text { da água usada para beber e } 60 \% \text { da água de } \\
\text { irrigação. Veja figura } 9.30 \text {. } \\
\text { Com a tecnologia disponível atualmente, a } \\
\text { agricultura poderia reduzir sua taxa de uso em até }\end{array}$ \\
\hline
\end{tabular}


de uso em até 50\%, as indústrias em até $90 \%$ e as cidades em um terço sem prejudicar a produção econômica ou a qualidade de vida.
$50 \%$, as indústrias em até $90 \%$ e as cidades em um terço sem prejudicar a produção econômica ou a qualidade de vida.

Fonte: Autoria própria.

Todo o conteúdo existente entre o $15^{\circ}$ e o $22^{\circ}$ parágrafos do TDC foi eliminado no TD. Este intervalo tratava de questões sociais, políticas e econômicas, além de contextualizar a posição do Brasil nas discussões internacionais sobre o assunto.

É possível observar também, que na reelaboração do texto adaptado há uma possível tentativa de simplificar o conteúdo apresentado, retirando expressões e palavras que poderiam comprometer a compreensão da leitura por alunos do $6^{\circ}$ ano. Tal fato é evidenciado no trecho destacado no quadro 4, onde as palavras "irracional" e a expressão "uma constante" são suprimidas na reelaboração da frase.

No quadro 5, percebe-se a eliminação de trechos nos quais governo, especialistas e ecologistas são citados e também as frases finais do TDC, as quais possuem caráter encorajador em relação aos comportamentos individuais para a preservação da água.

Quadro 5: Comparação entre o TDC ( $\left(23^{\circ}\right.$ parágrafo) e TD ( $6^{\circ}$ parágrafo) apresentando eliminações e reordenações.

\begin{tabular}{|c|c|}
\hline Texto de divulgação científica & Texto didático \\
\hline $\begin{array}{l}\text { Faz pouco tempo que o mundo acordou para a } \\
\text { importância econômica e estratégica da água. } \\
\text { Mas, em meio a divergências sobre a posse e o } \\
\text { destino da água, já aflorou um consenso } \\
\text { mínimo. Especialistas, empresários e } \\
\text { ecologistas concordam que a ameaça de escassez } \\
\text { é real, mas que há tempo para evitá-la. Para isso, } \\
\text { é preciso estancar o desperdício, recuperar as } \\
\text { reservas poluídas, garantir o direito à água para } \\
\text { os mais pobres e criar projetos de educação } \\
\text { ambiental. A educação, dizem os especialistas, é } \\
\text { importante porque a ação de cada um é maior } \\
\text { do que qualquer intervenção que governos ou } \\
\text { empresas podem fazer. Saber qual é } \\
\text { verdadeira dimensão da ameaça é o primeiro } \\
\text { passo para vencer o problema. Portanto, ao ler } \\
\text { essa reportagem, você está fazendo a sua parte. }\end{array}$ & $\begin{array}{l}\text { A ameaça de escassez de água é real, mas há } \\
\text { tempo para evita-la. É preciso estancar o } \\
\text { desperdício recuperar as reservas poluídas, } \\
\text { garantir aos mais pobres o acesso a água e } \\
\text { investir em educacão ambiental. }\end{array}$ \\
\hline
\end{tabular}

Fonte: Autoria própria.

Com a drástica redução de parágrafos (de 23 parágrafos para 6), o TD não explora as questões socioeconômicas e geopolíticas relacionadas ao uso da água que são observadas no TDC. Também não deixa explícito, como faz o TDC, a rapidez com que 
este recurso tem sido consumido. Dentre as eliminações realizadas, observa-se trechos sobre algumas consequências graves do uso sem parcimônia da água, temática importante para um pensamento mais completo em relação as questões ambientais.

No estudo de Souza e Rocha (2014), onde foi analisado o TD de ecologia inserido no $\mathrm{LD}$ do $6^{\circ}$ ano, os resultados também apresentaram uma significativa redução de conteúdo, passando de 33 para apenas 4 parágrafos. As consequências desta redução também promovem a omissão de questões importantes abordadas no TDC base. Os achados de Martins, Cassab e Rocha (2001) também apontam para essa expressiva redução do TDC para o TD.

Ressalta-se que na reelaboração do texto adaptado a maioria dos parágrafos conta apenas com uma operação linguística. Observa-se também a utilização de parágrafos do TDC com poucos termos lexicais e não se nota grandes mudanças linguísticas e estruturais na adaptação realizada. Este resultado é similar ao encontrado por Martins, Cassab e Rocha (2001, não paginado), destacando que:

Se por um lado elas permitem tornar a leitura do texto mais acessível a um público de não especialistas, por outro nos cabe perguntar em que medida estas operações transformam padrões lingüisticos [sic] talvez fundamentais que caracterizam o pensamento e atividade científica.

Ao todo, no discorrer do texto adaptado ocorrem: dois acréscimos, duas reelaborações, duas reordenações e oito eliminações. Dito isto, é possível concluir que o TD faz o uso maior de eliminação de trechos do que de reordenação, substituição e acréscimos.

\section{A NATUREZA DA CIÊNCIA NOS TEXTOS}

$\mathrm{O}$ entendimento mais aprofundado do processo de exploração, consumo e qualidade dos recursos hídricos é fundamental para que a população entenda sua relação com os aspectos sociais, econômicos, científicos e ambientais da situação de crise hídrica vivenciada. Assim, torna-se importante tal abordagem no ensino para que os estudantes tenham acesso, desde a educação escolar, às informações que possam mudar seus posicionamentos e estimular uma participação mais ativa e qualificada na defesa do meio ambiente.

De forma geral, o TD apresenta as formas em que a água se encontra no planeta e seus percentuais, explana sobre o aumento da população e do consumo deste recurso, informa sobre o desperdício e a contaminação de água pelas indústrias, agricultura e sociedade e, ainda, propõe a educação ambiental e a tecnologia como recurso para evitar a falta de água. No entanto, não menciona sobre legislação, conflitos 


\section{Ensino, Saúde e Ambiente - V10 (1), pp. 142-162, Abril. 2017}

geopolíticos, aspectos negativos das soluções tecnológicas, e a posição do Brasil nesse contexto. Mesmo na passagem em que apresenta a educação ambiental como ferramenta para educar a sociedade sobre o uso e o consumo deste recurso, o assunto é abordado de forma simplista.

O TDC apresenta como a água é finita e quais as consequências de sua possível escassez. Relaciona, ainda, as proporções disponíveis deste recurso no planeta, o quanto é viável para uso humano e a velocidade com a qual vem sendo consumido, abordando a preocupação com a falta de água própria para uso. Estas relações também são exploradas no TD sem grande reelaboração.

$\mathrm{O}$ texto original informa locais pouco mencionados ou conhecidos pela população em geral onde pode-se encontrar água doce própria para consumo, como os aquíferos, e argumenta sobre a preocupação do uso destes reservatórios para drenagem, em especial, nas regiões desérticas. Nesse ponto os textos divergem, pois, o TD não traz essas informações ao leitor, apresentando somente os lugares usualmente tratados quanto a presença de água doce. A falta de aprofundamento pode ter sido intencional, visto que o texto se encontra no capítulo do estado físico da água.

Além disso, na dissertativa do TD são retirados argumentos respaldados na fala de pesquisadores, não contemplando os leitores com informações acerca de como se chegaram as conclusões apresentadas. Resultados análogos foram encontrados nas análises de Souza e Rocha (2014), onde os autores acreditam que houve uma alteração na visão da Natureza da Ciência do ponto de vista do TD, pontuando que a omissão de relatos, menção às pesquisas e pequenas narrativas, impossibilitam ao estudante identificar a ciência no contexto socioambiental. Tais fatos corroboram com os pressupostos de Salém e Kawamura (1996), que identificam nos textos didáticos uma tendência em conduzir uma visão da ciência objetiva e neutra, sem apresentar aspectos importantes relacionados à Natureza da Ciência.

Acredita-se que para uma educação voltada à cidadania crítica é essencial abordar aspectos da Natureza da Ciência, como os interesses explícitos e implícitos dos diversos atores envolvidos em determinada situação e os conflitos sociais, políticos e econômicos que possam haver. Esses parâmetros auxiliariam em uma maior clareza na tomada de decisões sobre as questões sociais, tecnológicas, científicas e ambientais (GIL-PÉREZ et al., 2001; PRAIA et al., 2007). Neste sentido, o TD apresenta uma visão restrita com relação a atual crise hídrica e suas perspectivas futuras, pois não aborda as questões mais politizadas e contextualizadas, presentes no TDC. 
Divulgar a ciência de forma contextualizada e crítica é, portanto, essencial no processo de popularização do conhecimento. Nas relações de poder e de sedução entre cientistas e jornalistas, é necessário politizar essas relações, estabelecer limites e reconhecer as potencialidades em função do interesse público (CALDAS, 2010, p. 39).

Caldas (2010, p. 8), aponta ainda que os

(...) assuntos científicos e tecnológicos exigem cuidados adicionais na re / construção da informação. Face aos impasses e desafios provocados pela ciência moderna, essa discussão deve ser ampliada e contextualizada numa perspectiva histórica, política, econômica e social, qualificando a opinião pública para que, por meio de suas representações sociais, possa tornar-se sujeito ativo no processo de formulação de políticas públicas de C\&T [Ciência e Tecnologia] para o País.

Vale ressaltar que as supressões observadas no TD podem comprometer o entendimento da Natureza da Ciência. Além disso, a falta de interlocução entre o TD e o conteúdo abordado no capítulo pode influenciar na falta de contextualização do assunto. Nascimento (2005) também aponta em seus resultados a ausência de interlocução do TD com o conteúdo abordado no capítulo ao qual está inserido e a falta de aprofundamentos relacionados à aspectos da Natureza da Ciência que envolvem temas polêmicos para comunidade científica e sociedade.

Assim, percebe-se que o TD é mais informativo, limitado na função de estimular um pensamento crítico e reflexivo quanto as questões socioambientais, como orientado pelos Parâmetros Curriculares Nacionais (BRASIL, 1998). Dessa forma, observa-se no texto adaptado um subaproveitamento das oportunidades para a abordagem de aspectos da Natureza da Ciência que o TDC oferece e que poderiam potencializar o ensino e a educação ambiental, pois "o conhecimento não se constrói apenas com informações, mas, sobretudo, com o debate do contraditório e com tempo mínimo de reflexão para a tomada de decisão e escolhas conscientes" (CALDAS, 2010, p. 34).

\section{CONSIDERAÇÕES FINAIS}

Com o papel de trazer informações novas e esclarecer ao grande público a atual situação dos recursos hídricos, o TDC cumpre seu papel apresentando variados aspectos que esse discurso exige. Já no processo de reelaboração é possível perceber que grande parte da informação é dispensada, podendo interferir no propósito de apresentar informações atuais acerca do assunto. Parte do que é eliminado são referências de pesquisadores, que traz um pouco dos conflitos de interesses e divergência de posicionamento. Esta eliminação pode trazer conclusões equivocadas por parte dos alunos no que diz respeito a $\mathrm{NdC}$.

Outro aspecto evidente no texto adaptado são as eliminações de trechos que 
poderiam agregar ao debate um enfoque mais reflexivo e mais rico ao assunto abordado, como as informações de conflitos geopolíticos, a mercantilização da água, e a postura do Brasil diante desse contexto. Como já discutido, tal fato, pode ter sido intencional visto que o texto se encontra em um capítulo do LD com conteúdo mais objetivo, os estados físicos da água.

No entanto, a falta desses expostos traz uma visão superficial da própria problemática descrita no texto quanto este recurso. Uma abordagem mais completa no TD seria uma importante oportunidade para debater assuntos que envolvem a temática da educação ambiental, em um contexto marcado pela degradação permanente do meio ambiente e do seu ecossistema. Além de perder a oportunidade de dialogar com outras disciplinas, que também discutem este tema, como geografia e história.

No processo de reelaboração houve a retirada de termos lexicais de alta densidade. É entendido que há necessidade de uma escrita que seja compreensível ao público alvo, porém uma reelaboração que não apresenta nenhum termo léxico novo pode interferir na expansão de vocabulário científico dos alunos.

Cabe ressaltar o papel do professor como orientador do processo de leitura e aproveitamento do LD. A inserção do texto adaptado a um debate não exime o educador de realizar uma leitura crítica e agregar questionamentos e informações que possam contribuir no aprofundamento do conhecimento científico dos alunos (FERREIRA E QUEIROZ, 2012). Entende-se então, que o professor tem o potencial de ser um norteador, conduzindo o exposto a fim de agregar mais conhecimento científico aos estudantes.

Assim, corroborando com os achados de Rocha (2010), entende-se que a DC pode ser utilizada como forma de comunicação das questões sociais, científicas, tecnológicas e ambientais vivenciadas no ensino formal, contribuindo para a formação de indivíduos mais informados e preparados para atuar nas decisões cotidianas que afetam o bem-estar individual e social.

\section{REFERÊNCIAS}

BARATA, G. Papel social do cientista inclui divulgar seu trabalho. Ciênc. Cult. v. 60, n. 1, 2008.

BRASIL, SECRETARIA DE EDUCAÇAO FUNDAMENTAL. Parâmetros Curriculares Nacionais: Terceiro e quarto ciclos do ensino fundamental. Brasília: MEC/SEF, 1998, 138 p. Disponível em: http://portal.mec.gov.br/seb/arquivos/pdf/ciencias.pdf. Acessado em jan. 2017. 
BUENO, W. C. Jornalismo científico: conceito e funções. Ciência e Cultura. v. 37, n. 9, p. 1420-1427, 1985.

CALDAS, G. Divulgação científica e relações de poder. Inf. Londrina, v. 15, n. esp., p. 31 - 42, 2010. Disponível em:

http://www.uel.br/revistas/uel/index.php/informacao/article/view/5583. Acessado em jan. 2017. DOI: http://dx.doi.org/10.5433/1981-8920.2010v15n1espp31.

CUNHA, M. B.; GIORDAN, M. A divulgação científica como um gênero de discurso: implicações na sala de aula. In: Encontro Nacional de Pesquisa em Educação em Ciências, 7., 2009, Florianópolis. Atas... Florianópolis, 2009. 1 CD-ROM.

FERREIRA, L.N.A.; QUEIROZ, S.L. Textos de Divulgação Científica no Ensino de Ciências: uma revisão. Revista de Educação em Ciência e Tecnologia. v. 5, n. 1, p. 3 31, maio 2012. Disponível em:

https://periodicos.ufsc.br/index.php/alexandria/article/view/37695. Acessado em jan. 2017.

GEWANDSZNAJDER, F. Ciências $6^{\circ}$ ano - Planeta Terra. Projeto Teláris, $1^{\text {a }}$ edição, Editora Ática, 2012.

GIL, A. C. Como elaborar projetos de pesquisa. 5. ed. São Paulo: Atlas, 2010. 184p.

GIL-PERÉZ, D.; FERNÁNDEZ-MONTORO, I.; CARRASCOSA-ALIS, J.;

CACHAPUZ, A.; PRAIA, J. Para uma imagem não deformada do trabalho científico. Ciência \& Educação. v. 7, n. 2, p. 125-153, 2001.

GOMES, E. Dos laboratórios aos jornais: Um estudo sobre o jornalismo científico. Dissertação de mestrado do Programa de Pós-graduação em Letras e Lingüística. 1995.

GRIGOLETTO, E. O discurso de divulgação científica: um espaço discursivo intervalar. 2005. 267 f. Tese de Doutorado em Letras no Instituto de Letras, UFRGS, Rio Grande do Sul. Disponível em: https://www.ufrgs.br/ppgletras/defesas/2005/EvandraGrigoletto.pdf. Acessado em jan. 2017.

GRILLO, S.; DOBRANSZKY, E.; LAPLANE, A. Mídia impressa e educação científica: uma análise das marcas do funcionamento discursivo em três publicações. Cadernos Cedes. v. 24, n. 63, p. 215-236, maio/ago. 2004. Disponível em: www.scielo.br/pdf/ccedes/v24n63/22595.pdf. Acessado em jan. 2017.

LOUREIRO, J.M. Museu de ciência, divulgação científica e hegemonia. Ciência da Informação, v. 32, n. 1, p. 88-95, 2003.

MARTINS, I.; CASSAB, M.; ROCHA, M. B. Análise do processo de reelaboração discursiva de um texto de divulgação científica para um texto didático. Revista Brasileira de Pesquisa em Educação em Ciências. v. 1, n. 3, p. 1-9, 2001.

NASCIMENTO, T. O discurso da divulgação científica no livro didático de ciências: 
características, adaptações e funções de um texto sobre clonagem. Revista Brasileira de Pesquisa em Educação em Ciências. v. 5, n. 2, p. 1-13, 2005. Disponível em: https://seer.ufmg.br/index.php/rbpec/article/view/2261. Acessado em jan. 2017.

ORLANDI, E. P. Divulgação Científica e efeito leitor: uma política social urbana. In: . (Org.). Discurso e texto: Formulação e circulação dos sentidos.

Campinas/SP: Pontes, 2001. p. 149-162.

PRAIA, J.; GIL-PÉREZ, D.; VILCHES, A. O papel da Natureza da Ciência na Educação para a Cidadania. Ciência \& Educação. v. 13, n. 2, p. 141-156, jun. 2007. Disponível em: http://www.scielo.br/scielo.php?pid=S1516$73132007000200001 \&$ script=sci_abstract\&tlng=pt. Acessado em jan. 2017.

ROCHA, M. B. Textos de divulgação científica na sala de aula: a visão do professor de ciências. Revista Augustus, v. 14, n. 29, p. 24-34, 2010.

SALÉM, S.; KAWAMURA, M. O texto de divulgação e o texto didático; conhecimentos diferentes? In: V Encontro de Pesquisadores em Ensino de Física. Anais... São Paulo: Sociedade Brasileira de Física, 1996. Disponível em: http://www.sbfisica.org.br/v1/arquivos_diversos/EPEF/V/V-Encontro-de-Pesquisa-emEnsino-de-Fisica.pdf. Acessado em maio de 2017.

SILVA, H. C. O que é divulgação científica? Ciência e Ensino. v. 1, n. 1, p. 53-59, 2006. Disponível em: http://prc.ifsp.edu.br/ojs/index.php/cienciaeensino/article/view/39/98. Acessado em jan. 2017.

SOUZA, P. H. R. de; ROCHA, M. B. Análise do processo de Reelaboração Discursiva na incorporação de um texto de Divulgação Científica no livro de Ciências. R. Bras. de Ensino de C\&T. v. 7, n. 1, p. 53-69, 2014.

TARGINO, M. DAS G. Divulgação científica e discurso. Comunicação \& Inovação. v. 8, n. 15, p. 19-28, 2007. Disponível em:

seer.uscs.edu.br/index.php/revista_comunicacao_inovacao/.../524. Acessado em jan. 2017.

ZAMBONI, L. M. S. Heterogeneidade e subjetividade no discurso da divulgação científica. 1997. 211f. Tese de Doutorado em Linguística no Instituto de Estudos da Linguagem, Unicamp, Campinas. Disponível em:

http://www.fiocruz.br/brasiliana/media/ZamboniLilianMarciaSimoesTese.pdf.

Acessado em maio de 2017. 